\title{
Drying Kinetics of Paper Mill Sludge
}

\author{
Wan Yu, Xiao Liu, Huashan Su, Yangjun Zhang \\ College of Mechanical \& Power Engineering, China Three Gorges University, Yichang, China \\ Email:yuwan@ctgu.edu.cn
}

How to cite this paper: Yu, W., Liu, X., Su, H.S. and Zhang, Y.J. (2017) Drying Kinetics of Paper Mill Sludge. Energy and Power Engineering, 9, 141-148.

https://doi.org/10.4236/epe.2017.94B017

Received: January 14, 2017

Accepted: March 30, 2017

Published: April 6, 2017

\begin{abstract}
Drying experiments of two paper mill sludge were carried using hot air with a temperature range of $50^{\circ} \mathrm{C}-80^{\circ} \mathrm{C}$ and an air velocity of $0.96 \mathrm{~m} / \mathrm{son}$ a laboratory convective dryer. The drying characteristics were discussed and the drying kinetic equation was solved. The dependence of the reaction rate constant on the drying temperature was given by Arrhenius equation, and the activation energies for moisture diffusion in paper mill sludge sample A and B were found to be $21.53 \mathrm{~kJ} / \mathrm{mol}$ and $15.38 \mathrm{~kJ} / \mathrm{mol}$, respectively.
\end{abstract}

\section{Keywords}

Paper Mill Sludge, Water Content, Drying Kinetics, Activation Energy

\section{Introduction}

Paper mill sludge is a by-product of waste water treatment process in paper mill. Rapid economic development has brought rapidly growing of paper mill sludge yield. Compared to municipal sewage sludge, paper mill sludge contains more organic substance. Therefore, disposal of paper mill sludge through incineration has been encouraged. The water content of paper mill sludge is as high as $70 \%$ $80 \%$, which is harmful to incineration [1] [2]. Thermal drying to reduce water content has been proved to be an effective method for reducing the volume and weight, increasing the heating value [3]. More and more attentions have been paid into the incineration of paper mill sludge in recently years, but there is little attention on the drying kinetics of paper mill sludge [4] [5] [6]. Research on drying kinetics of other materials usually adopted drying model method [7] [8], so thermal analysis method was used for discuss the drying kinetics of paper mill sludge in this paper.

Two paper mill sludge samples were selected, and the drying experiments were completed with a constant air speed of $0.96 \mathrm{~m} / \mathrm{s}$ and a temperature range of $50^{\circ} \mathrm{C}-80^{\circ} \mathrm{C}$ on a laboratory convective dryer. The drying characteristics were 
discussed and the drying kinetic equation was solved. In addition, the reaction rate constant of moisture transfer and the activation energy for moisture diffusion during the thermal drying process were calculated.

\section{Experiments and Methods}

\subsection{Sample and Experiments}

The sludge samples used for experiments were collected from two different workshop of a paper mill in Wuhan. Received sludge was a kind of brown and loose material with high water content (wet basis), sample A was $74.86 \%$ and sample B was $75.9 \%$.

The experimental set up shown in Figure 1 mainly consisted of a blower, an electric heater and a drying chamber. Air was sent into electric heater by a blower whose rotational speed was controlled by a frequency converter. As a result, the air velocity in the drying chamber related to air flow was adjustable. The relationship between blower frequency and air velocity can be built by a standard anemometer before experiments. Air was heated in the electric heater and a temperature controller was used for controlling and maintaining the required air temperature of the drying chamber inlet. The accuracy of temperature controller was $1^{\circ} \mathrm{C}$. Paper mill sludge samples were spread on a salver which was placed on the electronic scale through a steadier. The electronic scale can achieve real time measuring of the sludge weight and send the data to computer with an accuracy of $\pm 1 \mathrm{~g}$ and measuring range of $5 \mathrm{~kg}$.

As a heterogeneous material with complex components and interior structure, little sludge sample can't reflect the whole characteristics well, so abundant sludge of $3.5 \mathrm{~kg}$ was selected for experiment every time. First, drying temperature (the air temperature of drying chamber inlet) and air velocity were set by temperature controller and frequency converter, respectively. Sludge sample was made into long strip with a diameter of $8 \mathrm{~mm}$ by special machine, and $3.5 \mathrm{~kg}$ sample was put on salver. In addition, little sample was selected to measure the initial water content in the thermostatic drying chamber. Sludge weight variation was recorded by electric scale at $0.5 \mathrm{~min}$ interval during the drying process in order to determine the drying curve. The drying data from different drying experiments were expressed as water content versus drying time and drying rate versus water content.

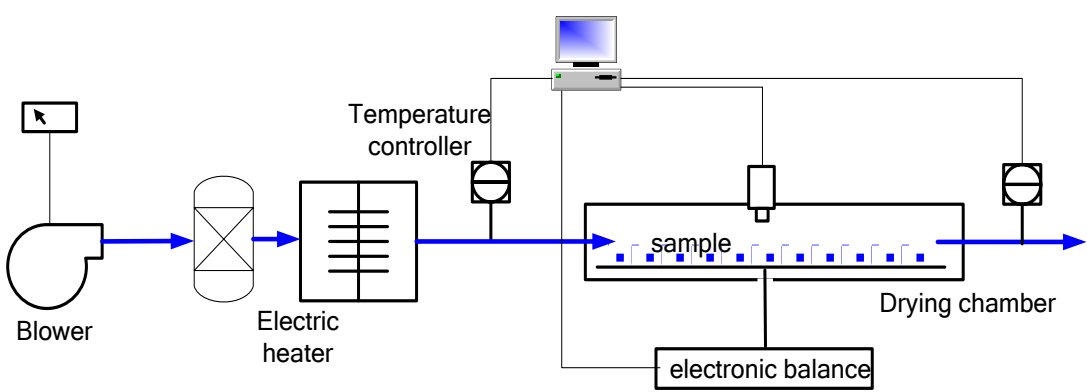

Figure 1. The schematic diagram of experimental equipment. 


\subsection{Drying Kinetics Analysis Method}

The drying process of paper mill sludge can be considered as a pyrolysis reaction, water and dry substance were the two pyrolysis products. Therefore, drying experiments can be considered as a thermal gravimetric experiment at steady low temperature. Then the thermal analysis method can be used to analyze the drying kinetics.

The relationship between reaction rate and sample weight loss rate can be described by reaction kineticmechanism equation as Equation (1).

$$
G(\alpha)=\int_{0}^{a} d \alpha / f(\alpha)=k t
$$

where $G(\alpha)$ was the reaction kineticmechanism equation, $\alpha$ was sample weight loss rate, $t$ was time, $k$ was the reaction rate constant. The Arrhenius equation was used to describe the relationship of temperature and reaction rate constant, which was shown in Equation (2).

$$
k=A \exp (-E / R T)
$$

where $A$ was preexponential factor, $E$ was activation energy, $T$ was thermodynamic temperature.

\section{Results and Discussion}

The paper mill sludge sample were dried using hot air of a temperature range of $50^{\circ} \mathrm{C}-80^{\circ} \mathrm{C}$ and constant air velocity of $0.96 \mathrm{~m} / \mathrm{s}$, and the drying characteristics were discussed.

\subsection{Drying Characteristics Curves}

The variations of water content versus drying time of paper mill sludge at various drying temperature were given in Figure 2 and Figure 3. As expected, the drying temperature contributed positively to the drying rate and negatively to the total drying time. It was caused by the increase of the heat transfer and mass transfer between the air and sludge sample along with the increase of temperature.

For example, the maximum drying rate of sample $\mathrm{A}$ at $50^{\circ} \mathrm{C}$ was $15 \mathrm{~g} /$ $\left(\mathrm{m}^{2} \cdot \mathrm{min}\right)$ while it was $31 \mathrm{~g} /\left(\mathrm{m}^{2} \cdot \mathrm{min}\right)$ at $80^{\circ} \mathrm{C}$. But the drying rate was not proportional to drying temperature, the rising speed became more and more slowly. While the drying temperature decreased from $80^{\circ} \mathrm{C}$ to $50^{\circ} \mathrm{C}$, the drying time of sample A between initial and 5\% water content was $260 \mathrm{~min}, 295$ $\min , 385 \mathrm{~min}$ and $505 \mathrm{~min}$, respectively. The drying curve can be divided to two parts, the accelerating and decreasing drying period, which was consistent with the results given by Celma [8]. The critical point between the two parts was the maximum drying rate during the drying process. The water content corresponding to the maximum drying rate dropped with the rising of drying temperature.

Results showed that the influence of drying temperature on drying rate became more and more obviously with the decreasing of water content. For example, when sludge sample $\mathrm{A}$ was dried at $80^{\circ} \mathrm{C}$ and $50^{\circ} \mathrm{C}$, the drying rate 

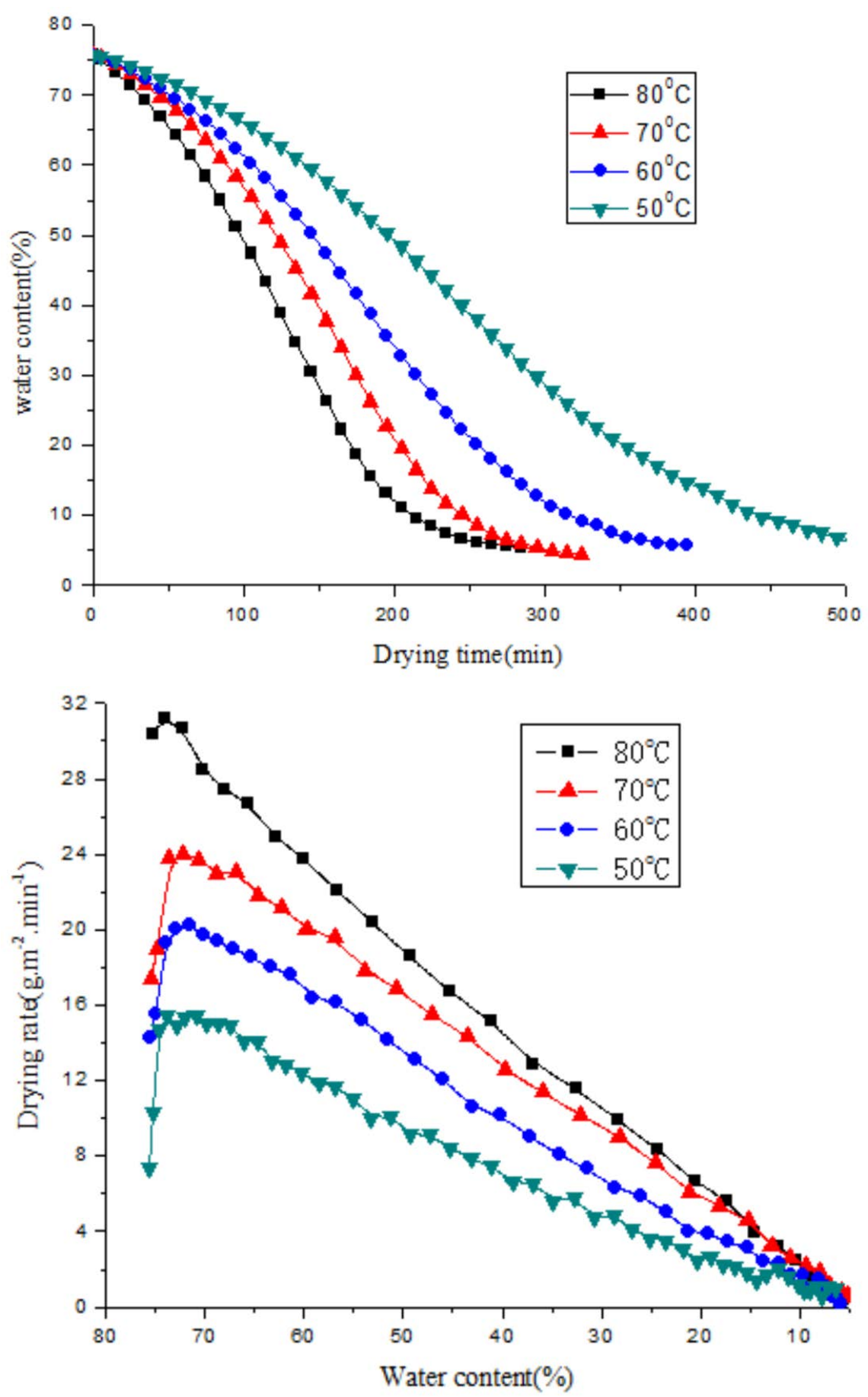

Figure 2. Drying characteristics at different drying temperature of sludge sample A.

was $23.8 \mathrm{~g} /\left(\mathrm{m}^{2} \cdot \mathrm{min}\right)$ and $12.3 \mathrm{~g} /\left(\mathrm{m}^{2} \cdot \mathrm{min}\right)$ when water content was $60 \%$, respectively. But the drying rate was $6.5 \mathrm{~g} /\left(\mathrm{m}^{2} \cdot \mathrm{min}\right)$ and $2.4 \mathrm{~g} /\left(\mathrm{m}^{2} \cdot \mathrm{min}\right)$ when water content was $20 \%$, respectively. At the earlier period of drying process, water evaporation happened on the sample surface, and interior water diffused to surface drives by humidity difference, so humidity of drying air had crucial effects on drying rate. At the later period of drying process, the sludge surface was dry, and water evaporation happened in the sludge interior. In 

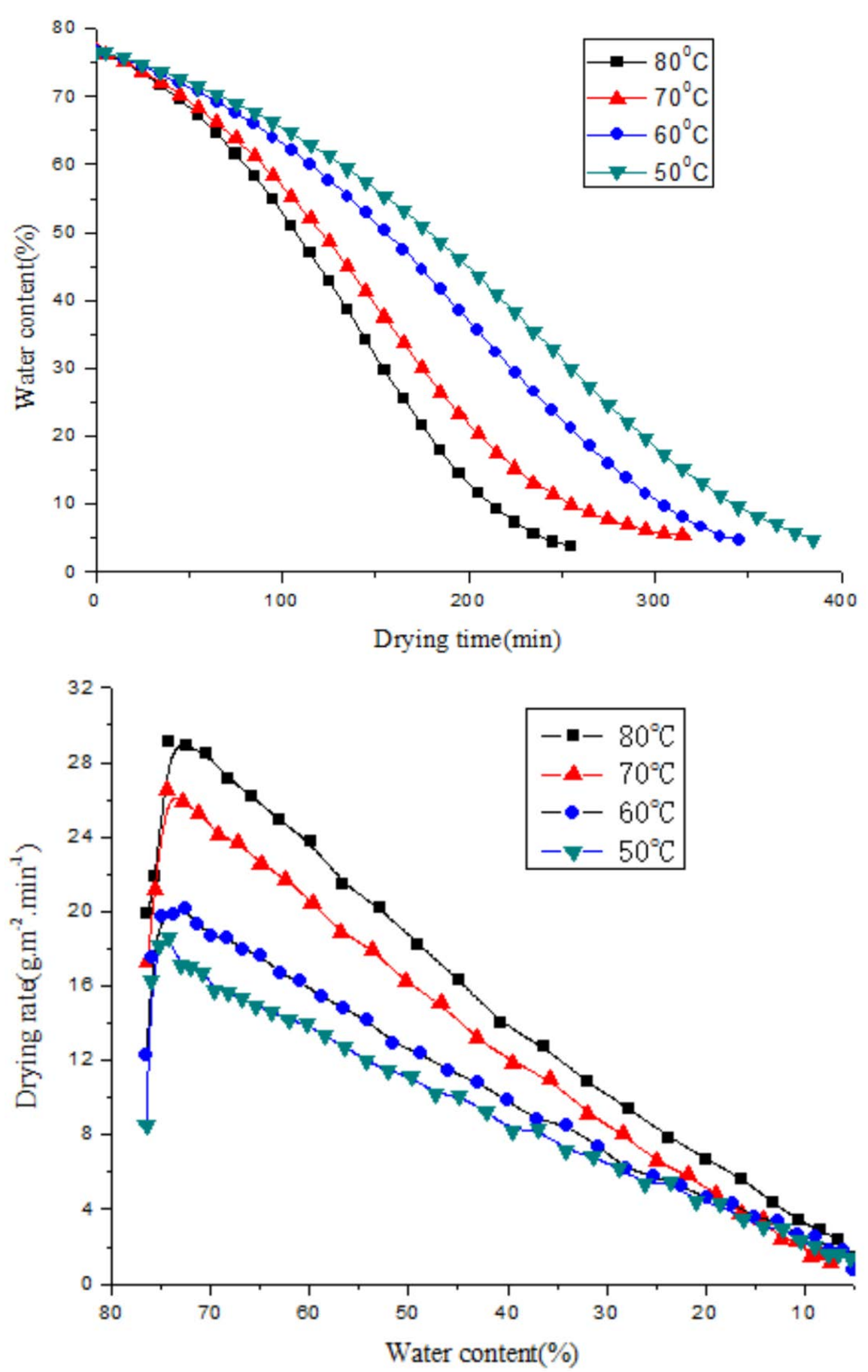

Figure 3. Drying characteristics at different drying temperature of sludge sample.

this case, drying temperature played the leading role in this period.

There were difference of drying characteristics between sample A and sample B. The drying time of sample A was longer than sample B, and the difference was influenced by the drying temperature.

\subsection{Drying Kinetic Analysis}

Drying experiments of paper mill sludge can be considered as a thermal gra- 
vimetric experiment at steady low temperature. According to the weight variation during the drying process, the sample weight loss rate was determined by Equation (3).

$$
\alpha=\frac{W_{0}-W}{W_{0}-W_{\infty}}=\frac{\Delta W}{\Delta W_{\infty}}
$$

where $W_{0}$ and $W$ were the initial weight of sludge sample and the real time weight at time $t$, respectively. $W_{\infty}$ was the final weight which can be considered as the drying substance weight. $\Delta W$ was the weight loss and $\Delta W_{\infty}$ was the maximum weight loss which was the water weight in sample.

The Inln method can be used for solve the reaction kinetic mechanism equation of paper mill sludge drying process. The criterion was the line slope on Avrami-Erofeev figure. According to the Avrami-Erofeev equation $1-\alpha=\mathrm{e}^{-k t^{m}}$, the natural logarithm equation can be given by Equation (4).

$$
\ln (-\ln (1-\alpha))=m \ln t+\ln k
$$

Then the fitting curve of $\ln (-\ln (1-\alpha))$ versus $\ln t$ can be built, and the slope of fitting curve was $m$. It was found that $\mathrm{m}$ was between 1.17 and 1.34 of sample $A$, while was between 1.27 and 1.38 of sample $B$.

Compared to the common reaction mechanism equation, the suitable $G(\alpha)$ can be described by Equation (5).

$$
G(\alpha)=R_{2}(\alpha)=1-(1-\alpha)^{0.5}=k t
$$

The $G(\alpha)$ value can be calculated by Equation (5) with the weight loss rate during the drying process at different drying temperature of two samples. The fitting curve of $G(\alpha)$ versus time $t$ can be built, and the slope of fitting curve was reaction rate constant $k$. The fitting results of reaction rate constant $k$ and coefficient of determination $R^{2}$ were shown in Table 1 .

It was found from Table 1 that the value of reaction rate constant $k$ varied in the range of $2.01856 \times 10^{-3}$ to $4.01873 \times 10^{-3}$ at temperature range of $50^{\circ} \mathrm{C}$ $80^{\circ} \mathrm{C}$ of sample A, while it varied in the range of $2.41998 \times 10^{-3}$ to $3.86391 \times 10^{-3}$ of sample B. The values of $k$ rose along with the rising of drying temperature.

The Arrhenius Equation (2) can be written in logarithmic form:

$$
\ln k=\ln A-\frac{E}{R} \frac{1}{T}
$$

In order to obtain the influence of drying temperature on the reaction rate

Table 1. Reaction rate constant of two sample.

\begin{tabular}{ccccc}
\hline \multirow{2}{*}{$\begin{array}{c}\text { Drying } \\
\text { temperature } \\
\left({ }^{\circ} \mathrm{C}\right)\end{array}$} & $k$ & $R^{2}$ & $k$ & $R^{2}$ \\
\cline { 2 - 5 } & \multicolumn{2}{c}{ Sample A } & $3.86391 \times 10^{-3}$ & 0.9869 \\
80 & $4.01873 \times 10^{-3}$ & 0.9803 & $3.40642 \times 10^{-3}$ & 0.9835 \\
70 & $3.31316 \times 10^{-3}$ & 0.9817 & $2.73915 \times 10^{-3}$ & 0.9936 \\
60 & $2.71764 \times 10^{-3}$ & 0.9819 & $2.41998 \times 10^{-3}$ & 0.9958 \\
50 & $2.01856 \times 10^{-3}$ & 0.9823 & & \\
\hline
\end{tabular}


constant, values of $\ln (k)$ were plotted versus $1 / T$ shown in Figure 4. The plot was found to be essentially a straight line with a slope of $-E / R$.

It was found that the values of activation energy $E$ for moisture diffusion during the thermal drying process of sample A and B were $21.53 \mathrm{~kJ} / \mathrm{mol}$ and 15.38 $\mathrm{kJ} / \mathrm{mol}$, respectively, while preexponential factor of Arrhenius equation was 6.24 and 0.73 . Results were similar to the activation energy of some materials in literatures given in Table 2. The activation energy of sample B was the smallest. But activation energy of sample A was higher than that of sludge of olive oil extraction but lower than that of olive pomace waste, lignite and carrot.

\section{Conclusion}

Drying experiments of two paper mill sludge were carried using hot air of a temperature range of $50^{\circ} \mathrm{C}-80^{\circ} \mathrm{C}$ and an air velocity of $0.96 \mathrm{~m} / \mathrm{s}$ at a laboratory convective dryer. The drying temperature contributed negatively to the total drying time, and the influence of drying temperature on drying rate became more and more obviously with the decreasing of water content. Results show the reaction rate constant $k$ varied in the range of $2.01856 \times 10^{-3}$ to $4.01873 \times$ $10^{-3}$ at temperature range of $50^{\circ} \mathrm{C}-80^{\circ} \mathrm{C}$ of sample $\mathrm{A}$, while it varied in the range of $2.41998 \times 10^{-3}$ to $3.86391 \times 10^{-3}$ of sample $\mathrm{B}$. The dependence of the
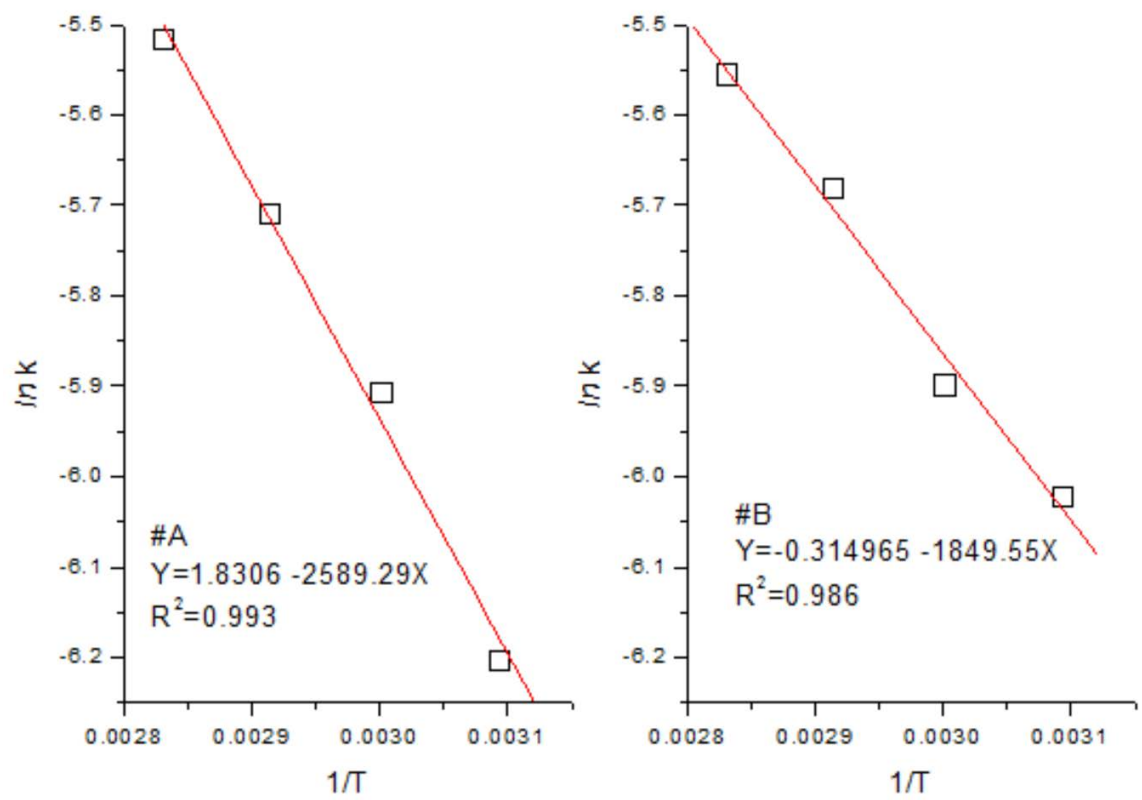

Figure 4. Influence of drying temperature on the reaction rate constant.

Table 2. Activation energy of some materials.

\begin{tabular}{ccc}
\hline Material & $\mathrm{E}(\mathrm{kJ} / \mathrm{mol})$ & References \\
\hline olive pomace waste & 29.06 & {$[9]$} \\
lignite & 27.92 & {$[10]$} \\
Sludge of olive oil extraction & 15.77 & {$[8]$} \\
Carrot & 28.36 & {$[11]$} \\
\hline
\end{tabular}


reaction rate constant on the drying temperature was given by Arrhenius equation, and the activation energies for moisture diffusion in paper mill sludge sample A and B were found to be $21.53 \mathrm{~kJ} / \mathrm{mol}$ and $15.38 \mathrm{~kJ} / \mathrm{mol}$, respectively.

\section{Acknowledgements}

This work was supported by Natural Science Foundation of Hubei province (2015CFB366), Science Research and Development Project of Yichang (A15302-a09), the Key Laboratory of Renewable Energy Electric-Technology of Hunan Province (2015ZNDL002).

\section{References}

[1] Yu, W. andLi, P.S. (2014)Determine the Moisture Distribution in Sewage Sludge by Drying Differential. Applied Mechanics and Materials, 665,404-407. https://doi.org/10.4028/www.scientific.net/AMM.665.404

[2] Werther,J. and Ogada, T.(1999)Sewage Sludge Combustion.Progress in Energy and Combustion Science, 25, 55-116.https://doi.org/10.1016/S0360-1285(98)00020-3

[3] Stasta,P.,Boran,J.,Bebar, L., Stehlik, P. and Oral, J. (2006) Thermal Processing of Sewage Sludge. Applied Thermal Engineering, 26, 1420-1426. https://doi.org/10.1016/j.applthermaleng.2005.05.030

[4] Cai, Z.L., Ma,X.Q., Fang, S.W., Yu, Z.S.and Lin, Y. (2016)Thermogravimetric Analysis of the Co-Combustion of Eucalyptus Residues and Paper Mill Sludge.Applied Thermal Engineering,106, 938-943. https://doi.org/10.1016/j.applthermaleng.2016.06.088

[5] Li, Y.Z., Ma,X.Q.,Xie,Z.Q. and Cai,Z.L. (2013)Investigation into Co-Combustion Kinetics of Paper Mill Sludge and Straw Via Thermogravimetric Analysis.Journal of South China University of Technology (Natural Science), 41, 12-17.

[6] Fava, Gabriele, Ruello, M.L. and Corinaldesi, V. (2011)Paper Mill Sludge Ash as Supplementary Cementitious Material.Journal of Materials in Civil Engineering,23, 772-776.https://doi.org/10.1061/(ASCE)MT.1943-5533.0000218

[7] Agrawal,S.G. andMethekar, R.N. (2017)MathematicalModel for Heat and Mass Transferduring Convective Drying of Pumpkin. Food and Bioproducts Processing, 101, 68-73.https://doi.org/10.1016/j.fbp.2016.10.005

[8] Celma,A. R., Rojas,S., Lopez, F., Montero,I. and Miranda, T.(2007)Thin-layer Drying Behaviour of Sludge of Olive Oil Extraction. Journal of Food Engineering, 80, 1261-1271.https://doi.org/10.1016/j.jfoodeng.2006.09.020

[9] Koukouch, A.,Idlimam, A.,Asbik,M.,Sarh,B., BoujemaaIzrar, Bostyn,S.,Bah,A., Ansari, O.,Zegaoui, O. and Amine, A.(2017)Experimental Determination of the Effective Moisture Diffusivity Andactivation Energy during Convective Solar Drying of Olive Pomacewaste.Renewable Energy, 101, 565-574.

https://doi.org/10.1016/j.renene.2016.09.006

[10] Zhao, P.F., Zhong,L.P., Zhu, R., Zhao,Y.M., Luo, Z.F. and Yang, X.L. (2016) Drying Characteristics and Kinetics of ShengliLignite Using Different Drying Methods. Energy Conversion and Management, 120, 330-337. https://doi.org/10.1016/j.enconman.2016.04.105

[11] Doymaz,I.(2004)Convective Air Drying Characteristics of Thin Layer Carrots. Journal of Food Engineering,61, 359-364. https://doi.org/10.1016/S0260-8774(03)00142-0 
Submit or recommend next manuscript to SCIRP and we will provide best service for you:

Accepting pre-submission inquiries through Email, Facebook, LinkedIn, Twitter, etc. A wide selection of journals (inclusive of 9 subjects, more than 200 journals)

Providing 24-hour high-quality service

User-friendly online submission system

Fair and swift peer-review system

Efficient typesetting and proofreading procedure

Display of the result of downloads and visits, as well as the number of cited articles Maximum dissemination of your research work

Submit your manuscript at: http://papersubmission.scirp.org/

Or contact epe@scirp.org 